\title{
Stylistic means of the cohesion implementation in Stephen King's fiction (case study of the novel "Storm of the Century")
}

\author{
T. Borysova \\ Kherson State University, Kherson, Ukraine \\ Corresponding author. E-mail: taipi13ram@bigmir.net
}

Paper received 17.03.18; Accepted for publication 25.03.18.

\section{https://doi.org/10.31174/SEND-Ph2018-159VI46-03}

\begin{abstract}
The article is devoted to the issue of the cohesion as the text category in modern linguistics and stylistic means of its implementation on the material of the story by Stephen King "Storm of the Century". The different types of linguistic units that are used to create explicit connectivity in the literary text are identified, their functions in fiction are analyzed in the course of our investigation. Particular attention is paid to the repetition and personalization as well, that dominate in the text that serves as our study material.

Keywords: category of coherence, cohesion, personification, repetition, implicity, explicity.
\end{abstract}

Our investigation is devoted to the issue of the cohesion as the text category (the category of coherence) in modern linguistics and stylistic means of its implementation on the material of the novel by Stephen King "Storm of the Century". The study of the specifics of the implementation of the category of coherence is an important aspect that has been actively developing in the last decades in such field of linguistics as Textology. A distinctive feature of the theory of the text is the approach to the text as a structural unity - the hierarchy of interrelated elements, while the constituent text units, having the dual nature of the word sign, which has a meaning and a formal embodiment, can, in some cases, coincide in volume with the text itself or associate with such units as a paragraph or a period.

There is a certain system of implementation of the category of coherence, which reflects the basic characteristics of the text as a multidimensional unit, correlated simultaneously with the structure and with the syntagmatic indicators of the language. The study of ways to implement the category of coherence in the literary text is necessary both in theoretical terms (as one of the stages of complex interpretation of the text), and in the pragmatic (the study of the linguistic nature of the text).

Topicality of the problem of this article is determined by the fact that on the material of the literary text we investigate the problems of identifying the linguistic nature of the text in general, the relation of the category of coherence and the category of integrity, the relationship of implicit and explicit means of connectivity, which leads to the general problem of meaning in linguistics. Studying various means of implementing the category of coherence in a literary text we also take into account the achievements of other sciences: psycholinguistics, which studies the processes of perception and formation of language; semiotics, which explores the most common features in the structure and functioning of various sign systems that operate in human society; literary studies, which task is to study the imagery and ideological content of the work of art, its connection with a certain epoch and the reflection of this connection in specific linguistic features. Approaches to the study of the peculiarities of the psychology of the author, which is hidden in the text, is also taken into account; formal logic that studies the general laws of human thinking and reveals the connection between language, thinking and other sciences. The main categories of the text are categories of integrity and coherence, which have common semantic (meaningful) indicators in terms of the implementation of global implicit connectivity.

Investigating coherence as a linguistic category of the text, many authors agree that in contrast to connectivity it is a purely informative property of the text (V.O. Lukin, A.I. Novikov, N.S. Valgina, etc. [4; 5; 2]). Emphasizing the semantic characteristics of coherence, researchers contrast these two categories as meaningful (integrity) and formal (cohesion). Since the text itself is a multidimensional phenomenon, an association consisting of linguistic units of different levels, the category of coherence functions at different levels of the text, combining the elements of the text (and not only the linguistic signs) into a single whole. The basic text-forming function of this category is the semantic correlation of the components of the text.

The category of coherence reflects the logical-semantic relations and relations between units of different language levels, which function in the structure of the text, and has two main methods of implementation: explicit and implicit. The dominant type of cohesion within a literary text is the implicit connectivity based on the unexpressed meanings arising in syntagmatic relations and expressiveness (components of the general knowledge of the author and the reader, that is, information that is known to the participants of the communication). Explicit connectivity is traditionally explored taking into account several types, based on the linguistic medium, serving as a brace of utterances in the text. Different types of connectivity are thoroughly explored in Textology investigations (L.G. Babenko, K.A. Filippov, N.V. Shevchenko and others. $[1 ; 6 ; 8])$. There are traditionally distinguished:

1) Phonetic means of cohesion, which do not relate to linguistic signs, but in literary texts, especially in poetic, the phonetic consonance is often the main means of creating a coherent text. Then we speak of the sound recording, which consists in picking up words with repeating sounds vowels and consonants. Depending on the repetition of specific sounds, assonance (repetition of vowels), alliteration (repetition of consonants) and sound repetitions are differentiated.

2) Lexical means of implementing a category of connectivity; they are more significant in the semantic and functional aspects, as it is at the lexical level of the text that the main semantic load lies in the implementation of the idea of the work. This structural duality of the word allows it to act in various relations with other identical, 
similar, correlated or opposed units. To lexical means of cohesion various types of repetition are usually included.

3) Explicit grammatical means of connectivity (traditionally combining the morphological and syntactic braces of statements, between which it is not always possible to draw a definite boundary: the prevailing of certain parts of speech in the text fragment; aspectual-temporal and modal correlation statements in the fragment of the text; syntactic parallel structures etc.

The novel under our analysis - "Storm of the Century" - is written in unusual format, actually it is a screenplay, so here are no vast descriptions, just characters' dialogues and the author's remarks concerning the setting. The story depicts a small island community experiencing a terrible winter storm. Having dealt with storms like that before, the town wasn't too worried about it at first. Unfortunately, the new one is bringing in more than just snow and wind, with the arrival of the storm Andre Linoge, the mysterious murderer, comes. Thus, the snow is not just used the basic element of the setting, but embodies the danger, horrific threat as well.

The analysis of S. King's novel shows that strain and emotions in the descriptions of the snow storm "of the century" are primarily transmitted by the author through the use of different types of repetition. Repetition is an important means of achieving the textual coherence and unity, with the help of which the author "switches" from one subject to another [7]. Therefore, repetition becomes a kind of background against which other semantic elements of the text seem brighter.

According to D. Tannen, the stylistic device of repetition contributes to a better understanding of the message contained in the text, because "the reader's attention, in the first place, is attracted by new information, and the information already known serves as the background necessary for a better perception of the new material" [9, p. 167]. On the base of the frequency of speech units in fiction new aesthetic signs emerge - the so-called key phrases or motifs. The re-emergence of any phrase makes the reader to return to its first application, causing the re-consideration which shows differences in meaning. One of the means of distinguishing leitmotif in the text is a "through" repetition, which also serves as a tool for architectonics and text styling. The leitmotif is repeated in the text several times, and each time it may become variational. Such repetitions, located remotely, contribute to the enrichment of meaning, emotional strain, leading the reader to the climax in the book [3]. For example, in the text under analysis we found the following fragments in the function of key phrases: ...driving snow..( 13 fragments registered throughout the text), ...blowing snow..(17 fragments) ...billowing snow...(7 fragments). Howling snow...(12 fragments).

The intensity of the flurry and the presence of the snow everywhere is emphasized with numerous repetition of compounds with the component snow. Nouns: snowsteps (1 unit registered in the text), snowsuit (2 units), snowfriendly (1 unit), snowpants (1 unit), snowbank (3 units), snowshoes (3 units), snowmobiles (16 units), snowfield (4 units), snowstorm (3 units), snowbird (3 units), snowdrift (4 units). Adjectives: snow-caked (2 units), snow-covered (6 units), snow-choked (2 units), snow-filled (1 unit), snow-clogged (1 unit).
A repeated use of capitalization in the text of the novel (more than 2000 fragments registered) serves to the emotional amplification and the effect of increasing the expression voltage:

Now there is only the WIND and the BLOWING SNOW. WIND is SHRIEKING.

The WIND RISES in a SHRIEK.

The WIND SCREAMS.

The WIND SHRIEKS, the SNOW SHEETS...

... a WILDERNESS OF SNOW...

SNOW SWIRLS and the WIND HOWLS..

The storm is HOWLING

DRIVING SNOW

BLINDING SNOWSTORM.

He opens the door and gets out into the HOWLING STORM.

...HOWLING WIND and DRIVING SNOW just outside.

As we see from the examples given above, the effect of the repetition and capitalization is intensified with the stylistic device of personification (it causes the readers' association of the snow and the wind with a wild dangerous beast), which plays an important role in creating the image of the predatory snow world, where the characters have appeared in the novel:

\section{The WIND SHRIEKS. \\ WIND HOWLS.}

WIND MOANS.

\section{The WIND RISES in a SHRIEK.}

Screaming blizzard.

Snow puffs.

...this place feels spooky, with the minimal lighting supplied by the gennie and the WIND SCREAMING outside.

In the author's description of the threatening snow storm which brought an eerie murderer to the town, we also constantly find the image of Death and objects connected with it (ghosts, burial, monster, death of choke etc.) which produce terrible, frightening impression. In the following examples these scary images are intensified with the help of epithet, simile and metaphor:

...And leaning against the milk box, buried to half its length in a snowdrift, is LINOGE'S CANE.

Snow is beautiful; snow is deadly;...

The snowmobile ... is almost buried in snow.

...the lampposts are buried halfway to their light globes.

A cane comes down, burying itself in the snow...

Three stages of snow-dressing, from a few inches to total burial.

The BLINKER LIGHT GOES DEAD. So do all the other brave little lights...

The snow falling so fast and hard...that the buildings looked like ghosts.

The streets are snow-choked.

... Its headlights cut twin cones through the snowchoked air.

...the heaters are almost buried in snow.

...Main Street is buried under at least four feet of snow...

...The stores have been all but buried under $\underline{\text { MONSTER }}$ DRIFTS

...She skis on toward the town hall, which is also $\underline{\text { buried }}$ in drifts. 
The cupola with the memorial bell in it is almost buried, and the brick town hall building itself looks ghostly.

The lighthouse is hardly there, only a dim white ghost in the swirling snow.

SNOW SWIRLS into the room, twisting in ghostly cyclones.

The sheers billow like ghostly arms.

Snow falling so thick and fast that the store looks like a ghost...

...we really can't see much at all now except for a couple of houses and some ghostly trees...

In the following examples of simile the snow, being traditionally a synonym of purity, is compared with not dangerous, yet unpleasant, unclean objects:

Snow... like bundles of dirty laundry.

Snow...it's scattered across the shoulders of his topcoat like dandruff.

Besides, in the text of the novel the snow is constantly unified with the darkness thus creating unusual association (white darkness):

He disappears into the dark and the snow.

Then it got dark again. At first I thought it was night, but it wasn't. It was the storm clouds.

THE PREACHER melts into DARKNESS ... but a snowy DARKNESS.
JOANNA... slips out the back door into the HOWLING DARK.

The picture of a horrible disaster is also created with the help of hyperbole and metaphoric comparisons of snow with disturbing images of a tidal wave, a web of a dangerous spider, a veil of a wizard:

We're talking hurricane-force winds and phenomenal amounts of snow, combining to create the sort of drifting you normally only see on the Arctic tundra.

Bearing down on it through the HOWLING SNOW is a huge wave almost a tidal wave.

Snow like like torn strands of cobweb.

Snow is also a veil, like the one the magician uses to hide his sleight of hand

Thus, the analysis of the novel "Storm of the Century" by Stephen King made it possible to come to the conclusion that among the stylistic means of the coherence implementation the use of repetition dominated throughout the text. Personification that allowed the reader to get a holistic view of the threatening predatory snow storm that is able to kill, "choke", "bury" the characters was also extensively used, as well as the repeated epithets and simile which, being intensified with the help of capitalization, created the image of the "deadly" supernatural force.

\section{REFERENCES}

1. Babenko L.G. Linguistic analysis of a literary text / 6. Filippov K.A. Text Linguistics: lectures / K.A.Filippov. - St. L.G.Babenko, Yu.V.Kazarin. - M .: Flint Science. -496 p.

2. Valgina N.S. The theory of the text / N.S.Valgina. - M .: Logos, 2003. $-250 \mathrm{p}$.

3. Kozhevnikova K. On the connectivity aspects of the text as a whole / K. Kozhevnikova // Syntax of a text. - M., 1979. №7. - P. $49-68$.

4. Lukin V.A. Literary Text: Fundamentals of linguistic theory and analysis of elements. Textbook for philological specialties. / V.A. Lukin. - M.: Publishing House "Os-89", 1999. - 192 p.

5. Novikov A.I. Text and its semantic dominants / Ed. N.V. Vasilyeva, N.M. Nesterova, N.P. Peshkova. - M .: Institute of Linguistics, 2007. $-224 \mathrm{p}$.

Petersburg: Publishing house of St. Petersburg University, 2003. - $336 \mathrm{p}$.

7. Harlamova T.V. Text-forming means in oral speech (on the material of Russian and English languages) / T.V.Harlamova. - Saratov: Publishing House of Sarat. University Press, 2000. $-305 \mathrm{p}$.

8. Shevchenko N.V. Essentials of text linguistics: a tutorial/N.V Shevchenko. - M .: Prior-izdat, 2003. $-160 \mathrm{p}$.

9. Tannen D. Transcription conventions from Talking Voices: Repetition, Dialog and Imagery in Conversational Discourse / D. Tannen. - Cambridge: Cambridge University Press, 1989. $256 \mathrm{p}$.

10. URL:http://allking.ru/books/texts/storm_of_the_century/

Стилистические средства реализации категории связности в художественных произведениях Стивена Кинга (на материале романа "Storm of the Century")

Т. Борисова

Аннотация. Статья посвящена вопросу категории связности в современной лингвистике и стилистическим средствам реализации этой категории на материале рассказа Стивена Кинга "Storm of the Century". Определяются различные типы языковых средств, используемых для создания эксплицитной связности, анализируются их функции в художественном тексте. Особое внимание уделяется таким стилистическим средствам, как персонификация, метафора, образное сравнение, а также повтор, который доминируют в произведении, служащем материалом исследования.

Ключевые слова: категория связности, когезия, персонификация, повтор, имплицитность, эксплицитность. 